\title{
Pests status of coconut in managed and unmanaged garden
}

\author{
S.M. Wankhede*, V.V. Shinde and S.L. Ghavale \\ AICRP on Palms, Regional Coconut Research Station (D.B.B.S.K.V.V.), Bhatye, Ratnagiri (M.S.) India
}

\section{ARITCLE INFO}

Received : 11.05 .2019

Revised : 25.08 .2019

Accepted : 11.09 .2019

\section{KEY WORDS :}

Black headed caterpillar coconut, Eriophyid mite, Rhinoceros beetle, Red palm weevil

*Corresponding author:

Email : agr_agronomist@yahoo.co.in

\begin{abstract}
The major pests incidence and intensity on coconut was recorded during fixed plot survey. It was carried out at bimonthly interval from April 2018 to February 2019 at Regional Research Station, Bhatye, Ratnagiri jurisdiction. Two plots were selected for observations, one was well managed (good sanitation, use of fertilizes etc.) and another unmanaged (poor sanitation, no use of fertilizers etc.). The major pest status in managed garden was found minimum which recorded rhinoceros beetle (25.7\%), eriophyid mite $(41.7 \%)$ and mite grade index 0.71 . Whereas, maximum infestation of rhinoceros beetle (Oryctes rhinoceros L.), red palm weevil (Rhynchophorus ferrugineus $\mathrm{O}$.) and eriophyid mite (Aceria guerreronis Keifer) were observed 30.3, 0.3, 71.7 per cent, respectively and mite grade index was recorded 1.57 (moderate) in unmanaged garden. The average data of two fixed plots revealed that the maximum infestation (48.0\%) was observed in June 2018 and minimum incidence was observed in February 2019 which recorded 7.64 per cent. The infestation of red palm weevil and black headed caterpillar (Opisina arenosella W.) were recorded 1.11 and 0.64 per cent only in February 2019. The highest infestation of eriophyid mite was recorded 64.9 per cent in April, 2018 and least incidence (41.6\%) was observed in October, 2018. The mite damage grade index 1.39 (Moderate) was recorded in February 19. However, lowest (0.67) was observed in October, 2018.
\end{abstract}

How to view point the article : Wankhede, S.M. Shinde, V.V. and Ghavale, S.L. (2019). Pests status of coconut in managed and unmanaged garden. Internat. J. Plant Protec., 12(2) : 119-122, DOI : 10.15740/HAS/IJPP/12.2/119-122, Copyright@ 2019: Hind Agri-Horticultural Society. 